\title{
Neurologic syndromes related to anti-GAD65: Clinical and serologic response to treatment
}

Neurol Neuroimmunol Neuroinflamm 2020;7:e733. doi:10.1212/NXI.0000000000000733

In the article "Neurologic syndromes related to anti-GAD65: Clinical and serologic response to treatment" by Muñoz-Lopetegi et al., ${ }^{1}$ published online March 2, 2020, the y-axis label for figure 5's right graph should be "CSF anti-GAD65 concentration (IU/mL)." The editorial office regrets the error.

\section{Reference}

1. Muñoz-Lopetegi A, de Bruijn MAAM, Boukhrissi S, et al. Neurologic syndromes related to anti-GAD65: Clinical and serologic response to treatment. Neurol Neuroimmunol Neuroinflamm 2020;7:e696. doi: 10.1212/NXI.0000000000000696. 


\section{Neurology \\ Neuroimmunology \& Neuroinflammation}

\section{Neurologic syndromes related to anti-GAD65: Clinical and serologic response to treatment \\ Neurol Neuroimmunol Neuroinflamm 2020;7; \\ DOI 10.1212/NXI.0000000000000733}

This information is current as of April 15, 2020

Updated Information \&

Services

References

Permissions \& Licensing

Reprints including high resolution figures, can be found at:

http://nn.neurology.org/content/7/4/e733.full.html

This article cites 1 articles, 1 of which you can access for free at: http://nn.neurology.org/content/7/4/e733.full.html\#\#ref-list-1

Information about reproducing this article in parts (figures,tables) or in its entirety can be found online at:

http://nn.neurology.org/misc/about.xhtml\#permissions

Information about ordering reprints can be found online: http://nn.neurology.org/misc/addir.xhtml\#reprintsus

Neurol Neuroimmunol Neuroinflamm is an official journal of the American Academy of Neurology.

Published since April 2014, it is an open-access, online-only, continuous publication journal. Copyright (C) 2020 American Academy of Neurology. All rights reserved. Online ISSN: 2332-7812.

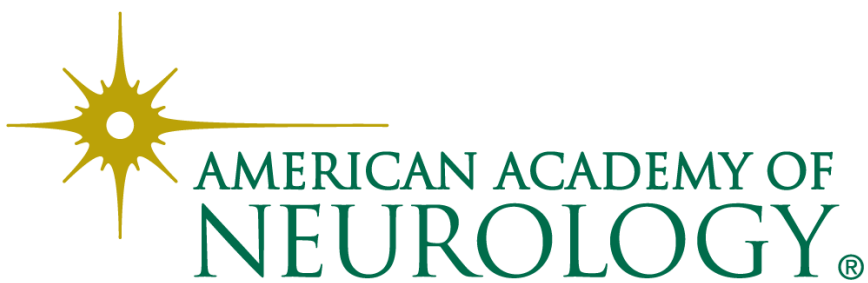

